\title{
PENGARUH ROE, DER, PER, DAN NILAI TUKAR TERHADAP RETURN SAHAM
}

\section{Ni Nyoman Sri Jayanti Perwani Devi ${ }^{1}$ Luh Gede Sri Artini²}

\author{
${ }^{1,2}$ Fakultas Ekonomi dan Bisnis Universitas Udayana, Bali, Indonesia \\ 1e-mail: jayantiperwani@gmail.com
}

\begin{abstract}
ABSTRAK
Tujuan penelitian ini adalah untuk mengetahui pengaruh Return on Equity (ROE), Debt to Earning Ratio (DER), Price to Earning Ratio (PER), dan Nilai Tukar Terhadap Return saham. Penelitian ini dilakukan pada seluruh perusahaan Property and Real Estate yang terdaftar di BEI. Jumlah sampel yang diambil sebanyak 36 perusahaan dengan menggunakan teknik sampling jenuh. Teknik analisis yang digunakan adalah teknik analisis regresi linier berganda. Berdasarkan hasil analisis ditemukan bahwa ROE berpengaruh positif dan signifikan terhadap return saham. DER berpengaruh negatif dan signifikan terhadap return saham, PER berpengaruh negatif signifikan terhadap return saham. Nilai tukar berpengaruh negatif dan tidak signifikan terhadap retun saham. Investor serta pihakpihak terkait yang berkepentingan diharapkan memerhatikan perubahan terhadap ROE, DER, dan PER karena memiliki pengaruh terhadap return saham, yang nantinya akan mempertimbangkan keputusan strategi investasi untuk meminimalkan risiko dan memaksimalkan return yang diperoleh.
\end{abstract}

Kata kunci: analisis fundamental, return saham

\begin{abstract}
The purpose of this study was to determine the effect of Return on Equity (ROE), Debt to Earning Ratio (DER), Price to Earning Ratio (PER), and Exchange Rate Against Stock Returns. This research was conducted on all Property and Real Estate companies listed on the IDX. The number of samples taken was 36 companies using saturated sampling techniques. The analysis technique used is multiple linear regression analysis techniques. Based on the results of the analysis it was found that ROE had a positive and significant effect on stock returns. DER has a negative and significant effect on stock returns, PER has a significant negative effect on stock returns. The exchange rate has a negative effect and is not significant to stock returns. Investors and other interested parties are expected to pay attention to changes to ROE, DER, and PER because they have an influence on stock returns, which will later consider investment strategy decisions to minimize risks and maximize returns obtained.
\end{abstract}

Keywords: fundamental analysis, stock returns 


\section{PENDAHULUAN}

Faktor penting yang harus diperhatikan perusahaan untuk membiayai aktivitas perusahaan adalah sumber dana. Sumber dana ditinjau dari asalnya meliputi sumber internal yang berasal dari dalam perusahaan dan sumber eksternal yang berasal dari luar perusahaan. Dana yang berasal dari sumber internal merupakan dana yang dihasilkan dari dalam perusahaan seperti laba perusahaan. Dana yang bersumber dari eksternal ialah dana yang berasal dari pihak-pihak luar perusahaan, seperti utang pada bank, kreditur maupun melalui investasi oleh para investor dalam pasar modal.

Pasar modal adalah pasar untuk memperjual-belikan instrumen jangka panjang, seperti : obligasi, saham, reksa dana, maupun instrumen lainnya. Pasar modal di Indonesia adalah Bursa Efek Indonesia (BEI). Bursa Efek Indonesia memiliki sembilan sektor, salah satunya adalah Sektor Property and Real Estate. Produk yang dihasilkan dari industri property and real estate berupa apartement, rumah toko (ruko), gedung perkantoran, perumahan, rumah kantor (rukan), serta pusat-pusat perbelanjaan. Perkembangan bisnis property and real estate cukup pesat dan dalam jangka waktu yang cukup lama sempat merajai bisnis di Indonesia. Bisnis property and real estate sering dipandang sebagai salah satu sektor bisnis yang mampu memberikan keuntungan jangka panjang sehingga menarik minat investor untuk menanamkan modalnya pada sektor bisnis ini.

Tujuan investor melakukan investasi adalah memperoleh return. Return saham adalah ukuran untuk menilai keseluruhan imbal hasil perusahaan (Ghi, 2015). Investor sangat tertarik pada return saham dan berharap untuk 
memaksimalkannya. Return saham juga memungkinkan untuk investor dalam membandingkan tingkat pengembalian suatu perusahaan dengan perusahaan lainnya (Jogiyanto, 2017:283). Return sangat penting bagi para investor atau pemilik modal, karena return merupakan harapan keuntungan di masa mendatang yang merupakan kompensasi atas waktu dan risiko yang terkait dengan investasi yang dilakukan oleh investor. Tingkat permintaan dan penawaran dari para investor akan memengaruhi tinggi rendahnya harga saham perusahaan, apabila harga saham tinggi maka return yang akan diperoleh para inverstor juga tinggi. Tingkat return yang tinggi akan meningkatkan laba dan pendapatan yang akan diperoleh investor dalam kegiatan investasi.

Kondisi return saham pada perusahaan properti and real estate di Indonesia selama periode 2015-2017 sempat mengalami penurunan yang cukup signifikan. Berikut disajikan data return saham perusahaan property and real estate yang terdaftar di Bursa Efek Indonesia selama periode 2015-2017.

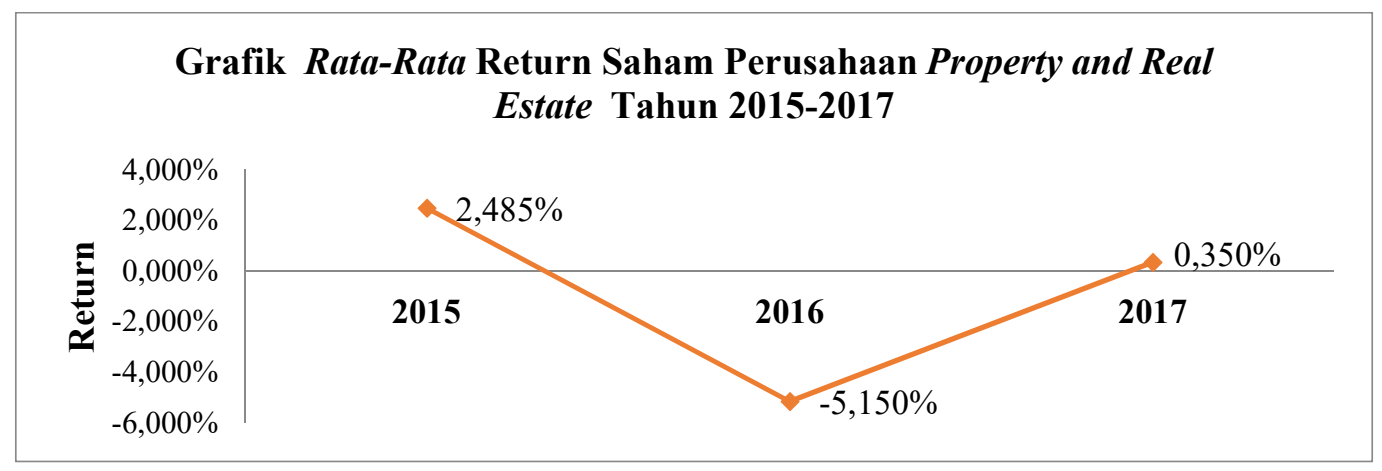

Gambar 1. Grafik Return Saham Perusahaan Property and Real Estate

Sumber: Bursa Efek Indonesia, 2018

Berdasarkan Gambar 1. terlihat bahwa grafik rata-rata return saham perusahaan property and real estate menunjukkan return saham sektor bisnis ini mengalami fluktuasi dari tahun 2015-2017. Tahun 2016 return saham pada sektor 
bisnis ini mengalami penurunan yang sangat tajam yaitu sebesar $-5.150 \%$. Pada tahun 2017 return saham mengalami kenaikan sebesar $0.350 \%$. Berdasarkan data pada gambar 1 maka dapat disimpulkan bahwa secara umum return saham pada perusahaan property and real estate di Indonesia selama periode 2015-2017 mengalami penurunan. Tahun 2017 tingkat return mengalami sedikit kenaikan namun belum mencapai titik awal kondisi return pada tahun 2015 .

Fluktuasi yang terjadi selama periode 2015-2017 pada return saham perusahaan property and real estate akan memengaruhi minat investor untuk melakukan kegiatan investasi pada sektor perusahaan ini. Investor akan lebih berhati-hati untuk melakukan investasi pada perusahaan yang mengalami fluktuasi return yang cukup tajam karena tujuan investor melakukan investasi adalah untuk memperoleh return, sehingga investor perlu pertimbangan yang rasional dengan mengumpulkan berbagai informasi yang diperlukan sebelum melakukan keputusan investasi (Puspitadewi dan Heny, 2016).

Informasi yang diperlukan oleh investor dalam pengambilan keputusan investasi dapat diperoleh melalui dua pendekatan analisis return saham pada perusahaan, yaitu Analisis Teknikal dan Analisis Fundamental. Analisis teknikal merupakan metode yang digunakan untuk memperkirakan harga saham dengan mengamati tren perubahan harga saham sehingga dapat membantu para investor menentukan kapan investor akan membeli, menjual, atau mempertahankan sahamnya dengan menggunakan indikator-indikator teknis atau menggunakan analisis grafik (Ginting dan Munthe, 2017). 
Jones (2014) mendefinisikan analisis fundamental adalah metode penilaian return saham dengan menggunakan financial analysis dan economic analysis untuk memperkirakan return saham. Analisis fundamental sangat erat kaitannya dengan kondisi perusahaan. Analisis Fundamental terdiri dari tiga tahapan, yaitu analisis makro, analisis industri dan analisis perusahaan (Tandelilin, 2010:339). Pada penelitian menggunakan analisis makro dan analisis perusahaan, analisis industri tidak digunakan karena pada penelitian ini menganalisis kondisi perusahaan berdasarkan laporan keuangan masing-masing perusahaan property and real estate yang terdaftar di BEI selama periode 2015-2017.

Analisis makro dilakukan dengan melihat kondisi perekonomian secara makro untuk mendapatkan penilaian perekonomian secara umum dan bertujuan untuk mengetahui pengaruhnya terhadap kondisi pasar saham. Analisis makro sangat penting dilakukan oleh investor karena adanya hubungan yang kuat antara kondisi lingkungan ekonomi makro dan kinerja di pasar modal. Tandelilin (2010:343) menjelaskan terdapat beberapa indikator yang digunakan dalam analisis makro seperti : Produk Domestik Bruto (PDB), Tingkat Inflasi, Tingkat Suku Bunga, dan Nilai Tukar Rupiah.

Penelitian ini menggunakan Nilai Tukar Rupiah dalam analisis makro, karena sebagian besar perusahaan property and real estate memiliki hutang dalam bentuk mata uang asing yaitu dolar. Berdasarkan Lampiran 8 terlihat bahwa dari 36 perusahaan property and real estate yang terdaftar di BEI selama periode 2015-2017 sebanyak 20 perusahaan memiliki hutang dalam mata uang asing sehingga risiko nilai tukar akan memengaruhi kondisi perusahaan. 
Terdepresiasinya nilai tukar rupiah akan memberikan sinyal negatif bagi para investor karena mencerminkan keadaan ekonomi Indonesia yang melemah sebagai dampak adanya inflasi, sehingga mendorong para investor untuk menjual saham di pasar. Tingginya jumlah penawaran saham di pasar akan berdampak pada menurunnya harga saham perusahaan sehingga return yang aakn diterima oleh investor juga akan menurun. Pernyataan tersebut selaras dengan penelitian yang dilakukan oleh Pervaiz et al. (2018), Firmansyah (2015), serta Rosiana dkk. (2014) yang menyatakan bahwa nilai tukar memiliki pengaruh yang positif signifikan terhadap return saham. Nugroho et al. (2018), Sutrisno (2017), serta Poluan (2013) menemukan hasil yang berlawanan yaitu nilai tukar berpengaruh negatif terhadap return saham.

Analisis perusahaan adalah analisis yang dapat dilakukan dengan metode analisis rasio keuangan. Rasio keuangan juga digunakan untuk melihat bagaimana kinerja keuangan suatu perusahaan (Imran, 2018). Pada penelitian ini untuk mengukur kinerja keuangan menggunakan rasio profitabilitas, solvabilitas (leverage), serta rasio penilaian pasar. Rasio profitabilitas digunakan untuk mengukur kemampuan perusahaan dalam memperoleh laba atau keuntungan. Investor umumnya akan melihat pertumbuhan profitabilitas yang mampu dihasilkan oleh perusahaan untuk menilai prospek perusahaan dimasa datang. Rasio solvabilitas digunakan untuk mengukur perbandingan antara hutang dengan modal yang dimiliki oleh perusahaan, karena proporsi hutang perusahaan akan berpengaruh terhadap kinerja perusahaan yang akan diamati oleh investor, dan rasio nilai pasar digunakan untuk mengukur pengakuan pasar terhadap kondisi 
keuangan yang dicapai oleh perusahaan. Analisis rasio pasar dipandang penting karena Tandelilin (2010:364) menyatakan bahwa komponen utama dalam analisis fundamental adalah rasio pasar.

Sudut pandang investor pada analisis perusanahaan adalah salah satu indikator penting untuk menilai prospek perusahaan dimasa datang adalah dengan melihat sejauh mana pertumbuhan profitabilitas perusahaan. Tandelilin (2010:372) menyatakan bahwa profitabilitas sangat penting diperhatikan untuk mengetahui sejauh mana investasi yang akan dilakukan investor di suatu perusahaan mampu memberikan return yang sesuai dengan tingkat yang disyaratkan investor. Rasio utama yang digunakan dalam menganalisis profitabilitas perusahaan adalah Return on Equity (ROE) yang menggambarkan kemampuan perusahaan dalam menghasilkan laba dengan memanfaatkan modal. Rasio ini digunakan dalam menganalisis return saham karena untuk meningkatkan pembayaran return, perusahaan harus mampu meningkatkan laba yang diperoleh (Husnan 2015:328).

ROE yang tinggi akan mencerminkan bahwa perusahaan berhasil menghasilkan keuntungan atas modal perusahaan. Laba merupakan informasi penting bagi investor sebagai pertimbangan dalam melakukan investasi pada suatu perusahaan. Hasil penelitian yang dilakukan oleh Alozzi dan Obiedat (2016) menyatakan peningkatan laba perusahaan mencerminkan peningkatkan ROE pada perusahaan. Peningkatan laba perusahaan akan memberikan sinyal kinerja perusahaan yang baik sehingga investor akan tertarik untuk membeli saham perusahaan. Tingginya permintaan saat jumlah penawaran yang tetap akan 
berdampak pada peningkatan harga saham, sehingga hal ini juga akan meningkatkan return saham. Artinya terdapat hubungan yang searah (positif) antara ROE dengan return saham. Penjelasan tersebut didukung oleh penelitian dari Ghi (2015), Wijesundera et al. (2015), serta Har dan Ghafar (2015) yang memperoleh hasil bahwa ROE berpengaruh positif signifikan terhadap Return saham. Penelitian yang dilakukan oleh Banerjee et al. (2016) menemukan hasil yang berlawanan yaitu ROE memiliki pengaruh negatif signifikan terhadap return saham.

Teori struktur modal, menyatakan jika posisi struktur modal berada diatas target struktur modal optimalnya, maka setiap pertambahan hutang akan menurunkan nilai suatu perusahaan. Struktur modal merupakan proporsi pendanaan dengan hutang (debt financing) perusahaan, yaitu rasio leverage perusahaan. Herawati (2017) menyatakan DER mencerminkan kemampuan perusahaan untuk memenuhi semua kewajiban yang ditunjukkan oleh beberapa bagian dari modal ekuitas yang digunakan untuk membayar utang. Risiko hutang tidak dilihat dari banyaknya hutang, tetapi dari rasio hutang terhadap modal yaitu dengan menggunakan DER (Liembono, 2016:42). Berdasarkan lampiran 4 dapat disimpulkan bahwa sebagian besar perusahaan property and real estate yang terdaftar di BEI selama periode 2015-2017 memiliki DER lebih dari 50\%. Tingkat DER pada sektor perusahaan ini tertinggi menyentuh angka $686.9 \%$. Artinya perusahaan dalam operasionalnya menggunakan lebih banyak hutang dibandingkan modal dan akan dihadapkan pada risiko hutang yang tinggi. 
Investor akan menghindari saham-saham perusahaan yang memiliki nilai DER yang tinggi karena nilai DER yang tinggi mencerminkan risiko perusahaan yang relatif tinggi. Situasi tersebut akan mengindikasikan kinerja perusahaan yang kurang baik dan menyebabkan investor menjual saham perusahan tersebut ke pasar karena kurang tertarik terhadap saham perusahaan. Jumlah permintaan dari investor yang menurun saat jumlah penawaran tetap, maka berdampak pada penurunan harga saham dan return perusahaan (Kasmir, 2015:158). Sari dan Kennedy (2017) menemukan hasil bahwa DER memiliki pengaruh negatif terhadap return saham. Artinya apabila DER meningkat maka akan menurunkan return saham. Hal ini selaras dengan penelitian yang dilakukan oleh Alozzi dan Obiedat (2016), Abdullah et al. (2015), serta Acheampong et al. (2014) yang menyatakan bahwa DER memiliki pengaruh negatif terhadap return saham. Penelitian yang dilakukan oleh Mailani dkk. (2017), Ibrahim dan Hussaini (2017) serta Nesa (2015) menemukan hasil yang berlawanan yaitu DER memiliki pengaruh positif terhadap Return saham.

Price Earning Ratio (PER) merupakan rasio yang membandingkan antara harga saham yang diperoleh dari pasar modal dan laba per saham yang diperoleh pemilik perusahaan yang disajikan dalam laporan keuangan (Jogiyanto, 2017:204). Tandelilin (2010:364) menyatakan dalam melakukan analisis perusahaan, investor harus mendasarkan kerangka pikirnya pada salah satu komponen utama dalam analisis fundamental, yaitu Price Earning Ratio (PER). Terdapat tiga alasan yang mendasari penggunaan PER. Pertama, karena pada dasarnya PER bisa digunakan untuk mengestimasi nilai intrinsik suatu saham. 
Kedua, return yang dibayarkan perusahaan pada dasarnya dibayarkan dari earning. Ketiga, adanya hubungan antara perubahan earning dengan perubahan harga saham. PER menunjukkan besarnya harga setiap satu rupiah earning perusahaan, selain itu PER juga merupakan ukuran relatif dari sebuah saham perusahaan.

Investor menggunakan PER sebagai salah satu indikator fundamental karena dipandang mampu memberikan kemudahan dalam perhitungan dan interpertasi (Meric et al., 2017). Nilai PER yang semakin tinggi akan mengindikasikan bahwa kinerja perusahaan juga semakin baik. Jitmaneeroj (2017) mengemukakan bahwa PER yang tinggi akan meningkatkan harapan investor untuk memperoleh tingkat return yang tinggi. Investor cenderung akan melakukan investasi pada perusahaan yang memiliki nilai PER tinggi.

Hasil penelitian yang dilakukan oleh Karami et al. (2014) menemukan bahwa PER memiliki pengaruh positif terhadap returun saham, karena PER yang tinggi akan mengindikasikan harga per lembar saham perusahaan tinggi. Kondisi tersebut akan meningkatkan permintaan investor atas saham. Meningkatnya permintaan saham berdampak pada peningkatkan harga saham yang selanjutnya akan meningkatkan return yang diterima oleh investor. Hasil serupa juga ditemukan oleh Ozturk dan Karabulut (2018), Putri dan Purbawangsa (2017) serta Sari dan Kennedy (2017) membuktikan bahwa PER memiliki pengaruh positif signifikan terhadap return saham. Hautauruk et al. (2014), serta Wijesundera et al. (2015) menemukan hasil yang berlawanan yaitu PER memiliki pengaruh negatif signifikan terhadap return saham. 
Return on Equity (ROE) adalah rasio profitabilitas yang menggambarkan kemampuan perusahaan dalam memberi keuntungan bagi investor dengan menunjukkan persentase laba bersih yang tersedia untuk modal yang digunakan oleh perusahaan. Nilai ROE yang tinggi, mencerminkan bahwa perusahaan berhasil menghasilkan keuntungan dari modal yang tersedia. Peningkatan ROE mencerminkan profitabilitas perusahaan yang baik sehingga mendongkrak nilai jual perusahaan. Meningkatnya nilai jual perusahaan akan meningkatkan jumlah permintaan saham perusahaan. Meningkatnya jumlah permintaan saat penawaran tetap maka berdampak pada peningkatan harga saham perusahaan, sehingga hal ini akan berkolerasi dengan peningkatan pemberian return saham.

Keadaan tersebut menunjukkan adanya pengaruh positif antara ROE dengan return saham. Pernyataan ini didukung dengan hasil penelitian yang dilakukan oleh Ghi (2015), Alozzi dan Obiedat (2016), Wijesundera et al. (2015), Har dan Ghafar (2015), serta Sari (2017) yang memperoleh hasil penelitian bahwa ROE berpengaruh positif signifikan terhadap return saham. Berdasarkan uraian diatas maka hipotesis dalam penelitian ini dapat dirumuskan sebagai berikut:

$\mathrm{H}_{1}$ : $\quad$ ROE berpengaruh positif terhadap return saham

Debt to Equity Ratio (DER) menilai hutang dengan seluruh ekuitas perusahaan. Nilai DER yang tinggi akan mencerminkan bahwa struktur permodalan perusahaan lebih banyak memanfaatkan utang-utang relatif terhadap modal yang dimiliki. Semakin tinggi DER maka akan mencerminkan risiko perusahaan yang relatif tinggi. Pembiayaan dengan menggunakan hutang tinggi akan meningkatkan risiko keuangan perusahaan yang menyebabkan perusahaan- 
perusahaan menghadapi kesulitan keuangan dan kebangkrutan (Matemilola et al., 2017). Tingkat hutang yang tinggi akan menyebabkan beban bunga perusahaan semakin tinggi dan akan mengurangi keuntungan perusahaan. Investor akan cenderung menghindari saham-saham yang memiliki nilai DER yang tinggi, jika nilai DER perusahaan relatif tinggi maka akan mengurangi minat investor melakukan investasi. Kondisi tersebut akan menurunkan jumlah permintaan saham jumlah penawaran tetap, maka akan berdampak pada penurunan harga saham yang selanjutnya berdampak pada penurunan return yang mampu diberikan oleh perusahaan.

Penjelasan diatas menunjukkan adanya pengaruh yang negatif antara DER terhadap return saham. Pernyataan tersebut didukung dengan hasil penelitian yang dilakukan oleh Alozzi dan Obiedat (2016), Abdullah et al. (2015), Acheampong et al. (2014), serta Sari dan Kennedy (2017) yang menyatakan bahwa DER memiliki pengaruh negatif terhadap return saham. Berdasarkan uraian diatas maka hipotesis pada penelitian ini dapat dirumuskan sebagai berikut:

$\mathrm{H}_{2}$ : DER berpengaruh negatif terhadap return saham

Price Earning Ratio (PER) merupakan rasio yang membandingkan antara harga saham yang diperoleh dari pasar modal dengan laba per saham yang diperoleh oleh perusahaan (Jogiyanto, 2017:204). Semakin tinggi rasio PER akan mencerminkan bahwa kinerja perusahaan juga semakin membaik. Nilai PER yang tinggi juga menggambarkan harga per lembar saham suatu perusahaan akan cenderung meningkat, jadi apabila harga per lembar saham dan tingkat pertumbuhan laba suatu perusahaan meningkat, maka nilai PER juga akan 
meningkat, dengan demikian maka tingkat permintaan atas saham perusahaan akan meningkat. Kondisi demikian menyebabkan peningkatan harga saham yang berdampak pada peningkatan return saham.

Penjelasan diatas menunjukkan bahwa PER memiliki pengaruh positif terhadap return saham. Pernyataan tersebut diperkuat dengan hasil penelitian yang dilakukan oleh Ozturk dan Karabulut (2018), Putri dan Purbawangsa (2017), Safitri dkk. (2017), Sari dan Kennedy (2017), Artaya dkk. (2014), Karami et al. (2014) membuktikan bahwa PER memiliki pengaruh positif signifikan terhadap return saham, yang berarti bahwa semakin tinggi PER suatu emiten maka harga per lembar saham emiten akan cenderung meningkat dan return saham akan meningkat pula. Berdasarkan uraian diatas, maka hipotesis penelitian ini dapat dirumuskan sebagai berikut:

$\mathrm{H}_{3}$ : $\quad$ PER berpengaruh positif terhadap return saham

Terdepresiasinya nilai tukar Rupiah terhadap US dollar akan berdampak terhadap perusahaan yang melakukan transaksi dengan mata uang asing. Nilai tukar rupiah yang terdepresiasi mencerminkan kondisi perekonomian negara yang sedang melemah sebagai dampak adanya inflasi. Suatu negara jika berada dalam keadaan inflasi, maka pemerintah akan menaikkan tingkat suku bunga sehingga investor akan lebih tertarik untuk menabungkan dananya dan menjual sahamnya di pasar. Meningkatnya jumlah penawaran saham perusahaan di pasar akan berdampak pada penurunan tingkat harga saham sehingga return juga akan menurun. 
Pernyataan tersebut didukung dengan hasil penelitian yang dilakukan oleh Pernyataan tersebut selaras dengan penelitian yang dilakukan oleh Pervaiz et al. (2018), Firmansyah (2015), dan Rosiana dkk. (2014) yang menyatakan bahwa nilai tukar memiliki pengaruh yang positif signifikan terhadap return saham. Berdasarkan uraian diatas, maka hipotesis penelitian ini dapat dirumuskan sebagai berikut:

$\mathrm{H}_{4}$ : Nilai tukar berpengaruh positif terhadap return saham.

\section{METODE PENELITIAN}

Penelitian ini dilakukan pada perusahaan Property and Real Estate yang terdaftar di BEI pada periode 2015-2017. Alasan penelitian dilakukan pada komoditi perusahaan tersebut karena adanya fenomena sebagian besar return saham pada komoditi perusahaan property and real estate mengalami penurunan.

Objek dalam penelitian ini adalah Return on Equity, Debt to Equity Ratio, Price Earning Ratio dan Return saham pada perusahaan Property and Real Estate yang terdaftar di BEI periode 2015-2017 serta nilai tukar rupiah terhadap US dollar periode 2015-2017.

Variabel terikat (Y) dalam penelitian adalah return saham. Variabel bebas (X) dalam penelitian ini antara lain: $\mathrm{X}_{1}=$ Return on Equity, $\mathrm{X}_{2}=$ Debt to Equity Ratio, $\mathrm{X}_{3}=$ Price Earning Ratio dan $\mathrm{X}_{4}=$ Nilai Tukar. Populasi dalam penelitian ini adalah perusahaan yang bergerak pada sektor Property and Real Estate yang terdaftar di BEI periode 2015-2017 yang berjumlah 36 perusahaan. Penentuan sampel penelitian ini menggunakan teknik sampling sensus atau teknik sampling jenuh. 
Metode pengumpulan data yang digunakan dalam penelitian ini adalah metode observasi non partisipan dengan cara melihat, mempelajari uraian-uraian dari buku, jurnal, serta mengutip catatan-catatan yang diperoleh dari Bursa Efek Indonesia (BEI) yang berupa laporan keuangan tahunan perusahaan Property and Real Estate serta data nilai tukar rupiah terhadap US dollar yang diperoleh dari situs resmi Bank Indonesia.

Analisis regresi linier berganda dipergunakan untuk mengetahui ketergantungan satru variabel terikat hanya pada satu variabel bebas dengan atau tanpa variabel moderator, serta untuk mengetahu ketergantungan satu variabel terikat pada variabel-variabel bebas. Teknik analsis ini digunakan untuk mengetahui pengaruh Return on Equity, Debt to Equity Ratio, Price Earning Ratio dan Nilai Tukar terhadap return saham pada perusahaan sektor Property and Real Estate yang terdaftar di BEI pada periode 2015-2017.

$\hat{Y}=\alpha+\beta_{1} X_{1}+\beta_{2} X_{2}+\beta_{3} X_{3}+\beta_{4} X_{4}+e$

Dimana :
$\hat{\mathrm{Y}} \quad:$ Return Saham
$\alpha \quad$ : Nilai Konstanta
$\mathrm{X}_{1} \quad$ : Return On Equity
$\mathrm{X}_{2} \quad$ : Debt to Equity Ratio
$\mathrm{X}_{3} \quad$ : Price Earning Ratio
$\mathrm{X}_{4} \quad$ : Nilai Tukar
$\beta_{1} \quad$ : Koefisien regresi Return on Equity $\left(\mathrm{X}_{1}\right)$
$\beta_{2} \quad$ : Koefisien regresi Debt to Equity Ratio $\left(\mathrm{X}_{2}\right)$
$\beta_{3} \quad$ : Koefisien regresi Price Earning Ratio $\left(\mathrm{X}_{3}\right)$
$\beta_{4} \quad$ : Koefisien regresi Nilai Tukar $\left(\mathrm{X}_{4}\right)$
e : error

Berdasarkan analisis regresi diamati Goodness of Fti-nya yaitu koefisien determinasi $\left(\mathrm{R}^{2}\right)$, uji kelayakan model (Uji F), dan hipotesis (Uji t). 


\section{HASIL DAN PEMBAHASAN}

Hasil dan pembahasan pada penelitian ini berupada analisis data deskriptif dilakukan untuk memberikan gambaran atau deskripsi mengenai variabel yang diteliti dimana terdiri dari Return on Equity $\left(\mathrm{X}_{1}\right)$, Debt to Equity Ratio $\left(\mathrm{X}_{2}\right)$, Price Earning Ratio $\left(\mathrm{X}_{3}\right)$, nilai tukar $\left(\mathrm{X}_{4}\right)$, dan return saham $(\mathrm{Y})$ yang terlihat dari Tabel 1 berikut:

Tabel 1.

Hasil Statistik Deskriptif Sampel Penelitian

\begin{tabular}{lrrrrr}
\hline & N & Minimum & Maximum & Mean & Std. Deviation \\
\hline Return Saham & 108 & $-0,8753$ & 1,8000 & $-0,009855$ & 0,3647838 \\
ROE & 108 & $-0,1522$ & 0,4116 & 0,082879 & 0,0923392 \\
DER & 108 & 0,035 & 6,869 & 0,777526 & 0,7754364 \\
PER & 108 & $-259,190$ & 2611,580 & 60,32497 & 295,07846 \\
Nilai Tukar & 108 & 13307,380 & 13391,970 & 13361,160 & 38,340573 \\
Valid N & 108 & & & &
\end{tabular}

Berdasarkan Tabel 1. dapat dijelaskan mengenai statistik deskriptif data yang digunakan pada penelitian ini, yakni hasil statistik deskriptif pada tabel diatas menunjukkan bahwa nilai minimum return saham sebesar -0,8753 atau $87.53 \%$ dan nilai maksimum sebesar 1,8000 atau $180 \%$. Hal ini menunjukkan bahwa besarnya return saham pada sampel penelitian ini berkisar antara $-0,8753$ sampai 1,8000 dengan rata-rata (mean) $-0,009855$ pada standar deviasi sebesar 0,3647838. Nilai return saham tertinggi pada Ristia Bintang Mahkotasejati Tbk tahun 2017 yaitu 1,8000 atau sebesar 180\%, sedangkan nilai return saham terendah pada Bumi Citra Permai Tbk tahun 2016 yaitu -0,8753 atau sebesar $87,53 \%$.

Nilai minimum Return on Equity (ROE) sebesar -0,152 atau sebesar -15,2\% dan nilai maksimim sebesar 0,4116 atau sebesar $41.16 \%$. Hal ini menunjukkan 
bahwa besarnya ROE pada sampel penelitian ini berkisar antara $-0,152$ sampai 0,4116 dengan rata-rata (mean) 0,082879 pada standar deviasi sebesar 0,0923392. Nilai ROE tertinggi pada Fortune Mate Indonesia Tbk tahun 2016 yaitu 0,4116 atau sebesar $41,16 \%$, sedangkan nilai ROE terendah pada Cowell Development Tbk tahun 2015 yaitu $-0,152$ atau sebesat $-15,2 \%$.

Nilai minimum Debt to Equity Ratio (DER) sebesar 0,035 atau sebesar $3,5 \%$ dan nilai maksimum sebesar 6,869 atau sebesar 686,9\%. Hal ini menunjukkan bahwa besarnya DER pada sampel penelitian ini berkisar antara 0,035 sampai 6,869 dengan rata-rata (mean) 0,777526 pada standar deviasi sebesar 0,7754364. Nilai DER tertinggi pada Alam Sutera Realty Tbk tahun 2017 yaitu 6,869 atau sebesar $686,9 \%$, sedangkan nilai DER terendah pada Ristia Bintang Mahkota Sejati Tbk tahun 2016 yaitu 0,035 atau sebesar 3.5\%.

Nilai minimum Price Earning Ratio (PER) sebesar -259,190 dan nilai maksimum sebesar 2611,580. Hal ini menunjukkan bahwa besarnya PER pada sampel penelitian ini berkisar antara $-259,190$ sampai 2611,580 dengan rata-rata (mean) 60,32497 pada standar deviasi sebesar 295,07846. Nilai PER tertinggi pada Pikko Land Development Tbk tahun 2017 yaitu sebesar 2611,580, sedangkan nilai PER terendah pada Gading Development Tbk tahun 2017 yaitu sebesar $-259,190$.

Nilai minimum nilai tukar sebesar Rp.13307,380 dan nilai maksimum sebesar Rp.13391,970. Hal ini menunjukkan bahwa besarnya nilai tukar pada sampel penelitian ini berkisar antara Rp.13307,380 sampai Rp.13391,970 dengan rata-rata (mean) 13361,160 pada standar deviasi sebesar 38,340573. Nilai tukar 
tertinggi pada tahun 2015 yaitu Rp.13391,970, sedangkan terendah pada tahun 2016 yaitu Rp.13307,380.

Model analisis yang digunakan pada penelitian ini adalah analisis regresi linier berganda. Model regresi linier berganda digunakan pada penelitian ini karena dapat menjelaskan pengaruh variabel bebas terhadap variabel terikatnya. Tujuan penelitian ini adalah untuk mengetahui pengaruh Return on Equity $\left(\mathrm{X}_{1}\right)$, Debt to Equity Ratio $\left(\mathrm{X}_{2}\right)$, Price Earning Ratio $\left(\mathrm{X}_{3}\right)$, dam Nilai Tukar terhadap (X) Return Saham (Y) pada perusahaan property and real estate periode 20152017. Hasil pengujian analisis regresi linier berganda dari penelitian ini disajikan pada Tabel 2 sebagai berikut:

Tabel 2.

Hasil Uji Regresi Linier Berganda

\begin{tabular}{|c|c|c|c|c|c|c|}
\hline & \multirow[t]{2}{*}{ Model } & \multicolumn{2}{|c|}{$\begin{array}{l}\text { Unstandardized } \\
\text { Coefficients }\end{array}$} & \multirow{2}{*}{$\begin{array}{c}\text { Standardize } \\
\text { Coefficients } \\
\text { Beta } \\
\end{array}$} & \multirow[t]{2}{*}{ Sig. } & \multirow[t]{2}{*}{$\begin{array}{l}\text { Hasil Uji } \\
\text { Hipotesis }\end{array}$} \\
\hline & & B & Std. Error & & & \\
\hline \multirow[t]{7}{*}{1} & (Constant) & 4,30161 & 7,64643 & & 0,575 & \\
\hline & ROE & 1,32503 & 0,25453 & 0,45001 & 0,000 & Diterima \\
\hline & DER & $-0,05802$ & 0,02761 & $-0,18232$ & 0,038 & Diterima \\
\hline & PER & $-0,00014$ & 0,00007 & $-0,17448$ & 0,045 & Diterima \\
\hline & Nilai Tukar & $-0,00033$ & 0,00057 & $-0,04875$ & 0,570 & Ditolak \\
\hline & Adjusted $\mathrm{R}^{2}$ & & & & & 0,224 \\
\hline & Sig. F & & & & & 0,000 \\
\hline
\end{tabular}

Hasil analisis pada Tabel 2 dapat dibuat persamaan regresi linier berganda sebagai berikut:

$$
Y=4,30161+1,32503 X_{1}-0,05802 X_{2}-0,00014 X_{3}-0,00033 X_{4}
$$

Keterangan :

$\begin{array}{ll}\mathrm{Y} & =\text { Return saham } \\ \mathrm{a} & =\text { Konstanta } \\ \mathrm{b} 1, \mathrm{~b} 2, \mathrm{~b} 2, \mathrm{~b} 3, \mathrm{~b} 4 & =\text { Koefisien regresi }\end{array}$




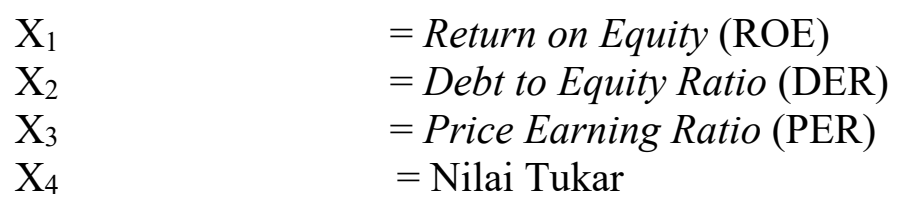

Persamaan regresi tersebut menjelaskan arah pengaruh dari masing-masing variabel bebas terhadap variabel terikatnya. Jika koefisien regresi memiliki tanda positif ini berarti bahwa variabel bebas memiliki pengaruh yang searah dengan variabel terikatnya, sedangkan koefisien regresi yang memiliki tanda negatif berarti bahwa variabel bebas memiliki pengaruh yang berlawanan arah dengan variabel terikatnya.

Persamaan diatas dapat dijelaskan berdasarkan masing-masing koefisien tersebut adalah nilai koefisien regresi Return on Equity (ROE) sebesar 1,32503 memiliki nilai yang positif menunjukkan adanya hubungan yang searah, apabila tingkat ROE naik sebesar satu persen, maka retrun saham meningkat sebesar 1,32503 satuan dengan syarat variabel bebas lainnya konstan atau sama dengan nol.

Nilai koefisien regresi Debt to Equity Ratio (DER) sebesar -0,05802 menunjukkan adanya hubungan yang berlawanan arah, apabila DER naik sebesar satu persen, maka return saham menurun sebesar 0,05802 satuan dengan syarat variabel bebas lainnya konstan atau sama dengan nol.

Nilai koefisien regresi Price Earning Ratio (PER) sebesar -0,00014 menunjukkan adanya hubungan yang berlawanan arah, apabila PER naik sebesar satu persen, maka return saham akan menurun sebesar 0,00014 satuan dengan syarat variabel bebas lainnya konstan atau sama dengan nol. 
Nilai koefisien regresi nilai tukar sebesar $-0,00033$ memiliki nilai negatif yang menunjukkan adanya hubungan yang berlawanan arah, apabila nilai tukar naik sebesar satu rupiah, maka return saham menurun sebesar 0,00033 satuan dengan syarat variabel bebas lainnya konstan atau sama dengan nol.

Koefisien determinasi berkisar antara nol sampai satu $\left(0 \leq \mathrm{R}^{2} \leq 1\right)$. Jika $\mathrm{R}^{2}$ semakin besar (mendekati satu), maka dapat dikatakan bahwa pengaruh variabel bebas $(\mathrm{X})$ adalah besar terhadap variabel terikat (Y). Hal ini berarti model yang digunakan semakin kuat untuk menerangkan pengaruh variabel bebas terhadap variabel terikat.

Tabel 3. Analisis Data Koefisien Determinasi $\left(\mathbf{R}^{2}\right)$

\begin{tabular}{ccccc}
\hline Model & R & R Square & Ajusted R Square & $\begin{array}{c}\text { Std. Error of the } \\
\text { Estimate }\end{array}$ \\
\hline 1 & $.503^{\mathrm{a}}$ & .253 & .224 & .208818 \\
\hline
\end{tabular}

Sumber: Data diolah, 2018

Nilai koefisien determinasi dilihat melalui nilai adjusted $R^{2}$. Nilai dari Adjusted $R^{2}$ pada penelitian ini telah disajikan pada Tabel 3 dapat dilihat bahwa nilai dari Adjusted $R^{2}$ sebesar 0,224 yang memiliki arti bahwa 22,4\% variasi perubahan return saham dapat dijelaskan oleh variabel Return on Equity (ROE), Debt to Equiy Ratio (DER), Price Earning Ratio (PER), dan nilai tukar. Sedangkan sisanya $77.6 \%$ dipengaruhi oleh variabel lain diluar model penelitian.

Adapun hasil dari pengujian kesesuaian model dalam penelitian ini telah disajikan pada Tabel 2 dapat dilihat bahwa nilai p-value (Sig. F) yakni 0,000 lebih kecil dari nilai $\alpha=0,05$. Hal ini menunjukkan bahwa penelitian ini layak untuk digunakan sebagai alat analisis untuk menguji pengaruh variabel independen pada variabel dependen. 
Berdasarkan Tabel 2. diperoleh hasil bahwa nilai signifikansi uji t dari variabel 0,000 lebih kecil dari $\alpha=0,05$ serta nilai koefisien beta sebesar 0,45001 . Hal ini berarti Return on Equity (ROE) berpengaruh positif dan signifikan terhadap return saham, sehingga hipotesis pertama dalam penelitian ini diterima.

Berdasarkan Tabel 2 diperoleh hasil bahwa nilai signifikansi uji t dari variabel 0,038 lebih kecil dari $\alpha=0,05$ serta nilai koefisien beta sebesar $-0,18232$. Hal ini berarti Debt to Equity Ratio (DER) berpengaruh negatif dan signifikan terhadap return saham, sehingga hipotesis kedua dalam penelitian ini diterima.

Berdasarkan Tabel 2. diperoleh hasil bahwa nilai signifikansi uji t dari variabel 0,045 lebih kecil dari $\alpha=0,05$ serta nilai koefisien beta sebesar $-0,17448$. Hal ini berarti Price Earning Ratio (PER) berpengaruh negatif dan signifikan terhadap return saham, sehingga hipotesis ketiga dalam penelitian ini diterima.

Berdasarkan Tabel 2 diperoleh hasil bahwa nilai signifikansi uji t dari variabel 0,570 lebih besar dari $\alpha=0,05$ serta nilai koefisien beta sebesar $-0,04875$. Hal ini berarti nilai tukar berpengaruh negatif dan tidak signifikan terhadap return saham, sehingga hipotesis keempat dalam penelitian ini ditolak.

Penelitian ini menemukan hasil bahwa Return on Equity (ROE) berpengaruh positif dan signifikan terhadap return saham. Hubungan positif ROE terhadap return saham menunjukkan apabila ROE meningkat maka return saham juga akan meningkat. Investor memperhatikan nilai ROE dalam pengambilan keputusan untuk berinvestasi pada sektor perusahaan property and real estate. ROE merupakan rasio profitabilitas yang mencerminkan kemampuan perusahaan menghasilkan keuntungan untuk pemegang saham atas modal yang telah 
diinvestasikannya. Tingkat ROE yang tinggi akan mempengaruhi investor untuk melakukan keputusan pembelian saham perusahaan karena dari sudut pandang investor pertumbuhan profitabilitas merupakan indikator penting untuk menilai prospek perusahaan dimasa datang. Tingginya permintaan atas saham perusahaan saat penawaran tetap maka akan meningkatkan harga jual saham perusahaan. Harga saham yang tinggi tentunya akan meningkatkan return yang akan diterima oleh investor.

Hasil penelitian ini sejalan dengan penelitian yang dilakukan oleh Ghi (2015), Alozzi dan Obiedat (2016), Wijesundera et al. (2015), Har dan Ghafar (2015), serta Sari (2017) dalam penelitiannya menyebutkan bahwa ROE berpengaruh positif dan signifikan terhadap return saham.

Penelitian ini menemukan hasil bahwa Debt to Equity Ratio (DER) berpengaruh negatif dan signifikan terhadap return saham. Hubungan negatif DER terhadap return saham menunjukkan apabila DER meningkat maka return saham akan menurun. Investor memperhatikan nilai DER dalam pengambilan keputusan investasi pada sektor perusahaan property and real estate. DER merupakan rasio yang menilai perbandingan antara tingkat hutang dengan seluruh ekuitas perusahaan. DER yang tinggi menggambarkan perusahaan menggunakan lebih banyak hutang dibandingkan ekuitas dalam melaksanakan operasional perusahaannya dan mencerminkan tingkat risiko perusahaan yang semakin tinggi, sehingga saham perusahaan tidak menarik lagi bagi investor maka investor akan mengambil keputusan untuk menjual saham perusahaan. 
Keputusan investor untuk menjual saham perusahaan menyebabkan penawaran saham perusahaan di pasar semakin meningkat. Jumlah penawaran yang tinggi sementara permintaan rendah berakibat pada penurunan harga saham. Rendahnya harga saham berakibat pada rendahnya tingkat return yang akan diterima oleh investor. Hasil penelitian ini sejalan dengan penelitian yang dilakukan oleh oleh Alozzi dan Obiedat (2016), Abdullah et al. (2015), Acheampong et al. (2014), serta Sari dan Kennedy (2017), dalam penelitiannya menyatakan bahwa DER berpengaruh negatif dan signifikan terhadap return saham.

Penelitian ini menemukan hasil bahwa Price Earning Ratio berpengaruh negatif dan signifikan terhadap return saham. Pengaruh negatif antara PER dengan return saham menunjukkan apabila terjadi peningkatan nilai PER perusahaan maka return saham akan mengalami penurunan. Investor memperhatikan PER dalam pengambilan keputusan investasi pada perusahaan property and real estate. Pada periode 2015-2017 nilai PER perusahaan property and real estate terlalu tinggi hingga menyentuh angka 2.611 kali. Investor memandang PER yang terlalu tinggi mencerminkan harga saham perusahaan yang terlalu mahal sehingga menurunkan daya beli investor. Penurunan daya beli investor akan berdampak pada penurunan permintaan saham property and real estate sehingga harga saham menurun dan berpengaruh terhadap penurunan return saham.

Hasil penelitian ini sejalan dengan penelitian yang diilakukan oleh Hautauruk et al. (2014), Andansari dkk. (2016), serta Wijesundera et al. (2015) 
yang mengemukakan bahwa PER memiliki pengaruh negatif signifikan terhadap return saham.

Penelitian ini menemukan hasil bahwa nilai tukar berpengaruh negatif dan tidak signifikan terhadap return saham. Pengaruh yang tidak signifikan mencerminkan bahwa investor tidak memerhatikan kondisi nilai tukar dalam melakukan keputusan investasi pada perusahaan properti and real estate di Indonesia. Pada perusahaan sektor property and real estate nilai tukar tidak berpengaruh terhadap keputusan investasi para invesrtor karena selama periode 2015-2017 proporsi penggunaan hutang luar negeri (USD) pada sektor perusahaan ini hanya sebesar $11,45 \%$. Penggunaan hutang dalam mata uang asing yang relatif kecil maka investor menilai bahwa faktor fluktuasi nilai tukar tidak mempengaruhi kondisi perusahaan.

Nilai Tukar tidak memberikan pengaruh secara signifikan terhadap return saham juga karena pada periode penelitian tidak terjadi fluktuasi yang tajam antara nilai tukar rupiah terhadap dollar sehingga tidak memengaruhi permintaan investor terhadap saham perusahaan, maka kondisi nilai tukar juga tidak memberikan pengaruh yang signifikan terhadap harga saham dan return saham yang akan diterima oleh investor.

Hasil peneltian ini sejalan dengan penelitian yang dilakukan oleh Hidayat dkk. (2017), Dirgasiwi dkk. (2016), Salim dan Simatupang (2016), Mahilo dan Parengkuan (2015) yang menyatakan bahwa nilai tukar berpengaruh negatif dan tidak signifikan terhadap return saham. 


\section{SIMPULAN}

Tinggi rendahnya Return on Equity (ROE) memengaruhi keputusan investor untuk melakukan investasi pada perusahaan property and real estate. ROE yang tinggi akan menarik minat investor untuk melakukan keputusan pembelian saham perusahaan karena bagi investor semakin tinggi ROE maka semakin baik prospek perusahaan karena semakin tinggi ROE maka semakin tinggi return saham yang diterima investor. Tinggi rendahnya Debt to Equity Ratio (DER) memengaruhi keputusan investor untuk melakukan investasi pada perusahaan property and real estate. DER yang tinggi mencerminkan risiko perusahaan yang tinggi sehingga investor akan memutuskan untuk menjual saham perusahaan karena semakin tinggi DER maka semakin rendah return saham yang diterima investor. Tinggi rendahnya Price Earning Ratio (PER) mempengaruhi keputusan investor untuk melakukan investasi pada perusahaan property and real estate. PER pada perusahaan property and real estate selama periode 2015-2017 sangat tinggi. Bagi investor jika PER perusahaan terlalu tinggi maka harga saham perusahaan terlalu mahal sehingga menurunkan daya beli investor.

Nilai tukar tidak memberikan pengaruh secara signifikan terhadap keputusan investor untuk melakukan keputusan investasi pada perusahaan property and real estate karena pada perusahaan ini tidak banyak melakukan transaksi dalam mata uang asing (USD) serta pada periode penelitian kondisi nilai tukar rupiah terhadap dollar (USD) tidak mengalami fluktuasi yang tajam.

Perusahaan sektor property and real estate hendaknya memerhatikan faktor internal terutama Return on Equity (ROE), Debt to Eauity Ratio (DER), Price 
Earning Ratio (PER). Berdasarkan hasil penelitiam, bahwa variabel ROE, DER, PER berpengaruh terhadap return saham sedangkan faktor eksternal yaitu nilai tukar tidak berpengaruh secara signifikan terhadap return saham.

Bagi investor penelitian ini diharapkan dapat memberikan informasi yang menjadi bahan pertimbangan dalam menentukan dan memutuskan investasi yang akan dilakukan.

Penelitian selanjutnya diharapkan dapat mengunakan variabel makro selain nilai tukar seperti tingkat suku bunga maupun inflasi untuk menguji pengaruh terhadap return saham pada perusahaan property and real estate karena hasil penelitian ini menunjukkan nilai tukar tidak memiliki pengaruh yang signifikan terhadap return saham perusahaan property and real estate. Melihat nilai Price Earning Ratio (PER) pada perusahaan property and real estate yang terlalu tinggi dan berakibat pada penurunan daya beli investor maka disarankan bagi perusahaan untuk melakukan stock split (pemecahan saham) agar pasar saham perusahaan kembali normal dan meningkatkan kembali daya beli investor.

\section{REFERENSI}

Abdullah, Mohammad Nayeem; Kamruddin Parvez; Tarana Karim; Rahat Bari Toohen. (2015). The impact of financial leverage and market size on stock returns on the Dhaka stock exchange: Evidence from selected stocks in the manufacturing sector The. International Journal of Economics, Finance and Management Sciences, Vol. 3 (1), hal.10-15.

Acheampong, Prince; Evans Agalega; Albert Kwabena Shibu. (2014). The Effect of Financial Laverage and Market Size on Stock Returns on Rhe Ghana Stock Exchange: Evidence on Selected Stocks in The Manufacturing Sector. International Journal of Financial Research, Vol. 5 (1), hal.125-134.

Andansari, Neni Awika; Kharis Raharjo; Rita Andini. (2016). Pengaruh Return on Equity (ROE), Price Earning Ratio (PER), Total Asset Turn Over (TATO), 
dan Proce to Book Value (PBV) Terhadap Return Saham (Studi Kasus Pada Perusahaan Manufaktur Sektor Makanan dan Minuman yang Terdaftar di BEI Periode 2008-(2014)). Journal of Accounting, Vol. 2 (2), hal.11-21.

Alozzi, Nurah Musa; Ghassan S. Obiedat. (2016). The Relationship Between the Stock Return and Financial Indicators (Profitability, Leverage): An Empirical Study on Mnufacturing Companies Listed in Amman Stock Exchange. Journal of Social Sciences, Vol. 15 (3), hal.408-424.

Artaya; Anom Purbawangsa; Sri Artini. (2014). Pengaruh Faktor Ekonomi Makro, Risiko Investasi dan Kinerja Keuangan Terhadap Return Saham Perusahaan di Bursa Efek Indonesia (BEI). E-Jurnal Ekonomi dan Bisnis Universitas Udayana, Vol. 3 (12), hal.689-701

Banerjee, Sanbad; Guha, Banhi; Gautam Bandyopadhyay. (2016). A Post Factor Analysis of Financial Ratios of Selected IPOs and its Impact on Grading: An Empirical Inquest. Journal of Business Studies Quarterly, Vol. 8 (1), hal.2334.

Bursa Efek Indonesia. (2018). Ringkasan Performa Perusahaan Tercatat. http://idx.co.id/data-pasar/laporan-statistik/ringkasan-performa-perusahaantercatat/. Diakses 5 Juli (2018).

Bursa Efek Indonesia. (2018). Laporan Keuangan dan Tahunan. http://www.idx.co.id/perusahaan-tercatat/laporan-keuangan-dan-tahunan/. Diakses. 10 Juli (2018).

Bursa Efek Indonesia. (2018). Profil Perusahaan Tercatat. http://www.idx.co.id/anggota-bursa-dan-partisipan/profil-partisipan/. Diakses. 10 Juli (2018).

Dirgasiwi, Danang Fiqri; Andrieta Shintia Dewi; Tieka Trikartika Gustyana. (2016). Pengaruh Inflasi, Nilai Tukar Mata Uang, ROA, dan DER Terhadap Return Saham: Studi Kasus Pada Perusahaan Sub Sektor Konstruksi Bangunan yang Terdaftar di BEI Periode (2011)-(2015). E-Journal Proceeding of Management, Vol. 3 (3), hal.3017-3024

Firmansyah, Muhammad. (2015). Analisis Pengaruh Inflasi, Nilai Tukar Bunga, dan Pertumbuhan Ekonomi terhadap Return Saham (Studi Kasus pada PT. Semen Indonesia, Tbk. Periode 2005-(2014)). Jurnal Ilmiah Mahasiswa FEB Universitas Brawijaya, Vol. 3 (2), hal.1-15.

Ghi, Tran Nha. (2015). The Impact of Capital Structure and Financial Performance on Stock Returns of The Firm House. International Journal of Information Research and Review; Vietnam, Vol. 2 (6), hal.734-737. 
Har, Wong Pik; Muhammad Afif Abdul Ghafar. ((2015)). The Impact of Accounting Earnings on Stock ReturnsThe Case of Malaysia's Plantation Industry. International Journal of Bussiness and Management; Malaysia, Vol. 10 (4), hal.155-165.

Hautauruk, M.R.; Hj.Sri M.; and H. Ardi P. (2014). Influence of Fundamental Ratio, Market Ratio and Business Performance to The Systematic Risk and Their Impacts to The Return on Shares at The Agricultural Sector Companies at The Indonesia Stock Exchange for The Period of (2010)-(2013). Academic Research International, Vol. 5 (5), hal.149-168.

Herawati, Aty. (2017). The Factors Affecting Initial Return on IPO Company in IDX 2007 - (2012). International Journal of Economic Perpectives; Faculty of Economics and Business Mercu Buana University (2017), Vol. 11 (1), hal.1459-1509.

Hidayat, La Rahmad; Djoko Setyadi; Musdalifah Azis. (2017). Pengaruh Inflasi dan Suku Bunga dan Nilai Tukar Rupiah Serta Jumlah Uang Beredar Terhadap Return Saham. Journal FEB Unmul, Vol. 19 (2), hal.148-154.

Husnan, Suad. (2015). Dasar-Dasar Teori Portofolio dan Analisis Sekuritas Edisi Kelima. Yogyakarta: YKPN.

Ibrahim, Idris; Hussaini Bala. (2017). Firms Specific Characteristics and Stock Market Returns (Evidence From Listed Food and Baverages Firms In Nigeria. International Journal of Information, Business and Management, Vol. 9 (1), hal.257-276.

Imran, Ume Salma. (2018). Predicting Stock Returns Using Financial Ratios: A Case of Pakistani Listed Companies. Journal of Aplied Finance and Economic Polic, Vol. 2 (1), hal.29-40.

Jitmaneeroj, Boonlert. (2017). Does Investor Sentiment Affect Price-Earnings Ratios?. Journal Economics and Finance, Vol. 34 (1), hal.1-16

Kasmir. (2015). Analisis Laporan Keuangan. Jakarta : Rajawali Pers.

Liembono. (2016). Analisis Fundamental Panduan Trading dan Investasi Saham. Surabaya: Brilliant.

Mahilo, Michael B.; Tommy Parengkuan. (2015). Dampak Risiko Suku Bunga, Inflasi, dan Kurs Terhadap Return Saham Perusahaan Makanan dan Minuman yang Go Public di Bursa Efek Indonesia. Jurnal EMBA, Vol. 3 (3), hal.1-10.

Mailani; Cipta; Suci. (2017). Pengaruh Current Ratio san Debt To Equity Ratio Serta Return On Asset Terhadap Return Saham Pada Perusahaan Indeks LQ- 
45 Yang Terdaftar di Bursa Efek Indonesia. Jurnal Jurusan Manajemen. Vol. $8(2)$, hal.97-105

Matemilola, Bolaji Tunde; Bany Ariffin; Anual Md Nasir; Azman Saini. (2017). Moderating Effects if Firm Age on Relationship Between Debt and Stock Returns. Journal of Asia-Pasific Busines,. Vol. 18 (1), hal.81-96.

Meric, Ekrem; Melik Kamisli; Fatih Temizel. (2017). Interaction Among Stock Price and Financial Ratio: The Case of Turkish Banking Sector. Red Fame Journal Applied Economic and Finance, Vol. 4 (6), hal.107-115.

Nesa, Anisa. (2015). Analisis Faktor-Faktor yang Mempengaruhi Return Saham (Studi Kasus pada Perusahaan Sub Sektor Automotive and Componentis yang Terdaftar di Bursa Efek Indonesia Periode ((2010)-(2014)). Jurnal Fakultas Ekonomi dan Bisnis Perbanan Institute, Vol. 1 (1), hal.72-86.

Pervaiz, Javed; Junaid Masih; Teng Jian Zhou. (2018). Impact of Macroeconomic Variabels on Kirachi Stock Market Return. International Journal of Economic and Financ, Vol. 12 (2), hal.28-34.

Poluan, Vriessylia Tania. (2013). The Influence of Macroeconomic Factors on Stock Return Listed in Composite Stock Price Index (IHSG) from 2008(2012). Journal EMBA, Vol. 1 (4), hal.306-315.

Puspitadewi, Indah dan Heny Rahyuda. (2016). Pengaruh DER, ROA, PER, dan EVA Terhadap Return Saham Pada Perusahaan Food and Baverage di BEI. E-Jurnal Manajemen Undud. Vol. 5 (3), hal.1429-1456.

Putri, Nirmala Kamiana dan Anom Purbawangsa. (2017). Pengaruh Kondisi Pasar Modal dan Rasio Keuangan Terhadap Return Saham di Bursa Efek Indonesia. E-Jurnal Manajemen Unud, Vol. 6 (8), hal.4269-4297.

Rosiana, Rita; Wulan Retnowati; dan Hendro. (2014). Pengaruh Rasio Profitabilitas, Rasio Aktivitas, Rasio Pasar, Firm Size, Tingkat Suku Bunga, dan Nilai Tukar terhadap Return Saham. Jurnal Bisnis dan Manajemen, Vol. 4 (1), hal.79-91.

Safitri, Dian Ayu; Budi Wahono; M. Agus Salim. (2017). Pengaruh Price To Book Value (PBV), Price Earning Ratio (PER), Debt To Equity Ratio (DER), dan Return On Asset (ROA) Terhadap Return Saham. Jurnal Riset Manajemen Prodi Manajemen Fakultas Ekonomi Unisma, Vol. 1 (2), hal.23-30.

Salim, Fifi Suryani; Apriani Simatupang. (2016). Kinerja Keuangan dan Kondisi Ekonomi Makro Terhadap Pengembalian Saham Perusahaan Property dan 
Real Estate yang Terdaftar di Bursa Efek Indonesia Periode Tahun (2011)(2014). Jurnal Administrasi Kantor, Vol. 4 (1), hal.47-67.

Sari, Fransisca Indah Permata; Posma Sariguna Johnson Kennedy. (2017). Pengaruh Faktor Fundamental Terhadap Return saham Perusahaan Mnaufaktur di BEI Periode 2009-(2015). Fundamental Management Journa,. Vol. 2 (6), hal.87-97.

Sari, Ratna Novita. (2017). Pengaruh Profitabilitas dan Kebijakan Devidend Terhadap Return Saham Perusahaan Manufaktur dengan Nilai Perusahaan Sebagai Variabel Intervening Periode (2010)-(2014). Jurnal Pendidikan dan Ekonomi, Vol. 6 (1), hal.88-95.

Sutrisno, Budiman. (2017). Pengaruh Nilai Tukar, Pertumbuhan Aktiva, Earning Per Share (EPS) dan Risiko Keuangan Terhadap Return Saham PerusahaanPerusahaan yang Terdaftar di Indeks LQ. Jurnal Manajemen dan Bisnis, Vol 1 (3), hal.23-27.

Tandelilin, Eduardus. (2010). Portofolio dan Investasi Teori dan Aplikasi, Edisi Pertama. Yogyakarta: Kanisius IKAPI.

Wijesundera; Weerasinghe; Krishna; Gunawardena; Peiris. (2015). Predictability of Stock Returns Using Financial Ratio. Empirical Evidence from Colombo Stock Exchange; Kelaniya Journal of Mnagement, Vol 4 (2), hal.44-55. 